\title{
Traditional Medicinal Plants Used to Treat Human and Livestock Ailments in Raya Alamata District, Northern Ethiopia
}

\author{
Abadi Hagos and Getachew Sime* \\ Department of Biology, College of Natural Sciences, Hawassa University, Hawassa, Ethiopia
}

\begin{abstract}
In Ethiopia, traditional medicine based mainly on medicinal plants, has been used for centuries for the treatment of human and animal health problems. The objective of this study was to document medicinal plants used to treat human and domestic animals ailments as well as the associate indigenous knowledge and conservation methods in Raya Alamata District in Northern Ethiopia. Ethno-botanical data were collected through semi-structured interviews, guided field walks, group discussions, field observations, preference ranking, paired comparison and direct matrix. The data were analyzed by descriptive statistics, informant consensus factor, and various ranking methods. Local communities heavily depend on traditional medicinal plants and associated knowledge for treating human and livestock ailments. However, medicinal plants and the associated knowledge are eroding mainly due to agricultural expansion, deforestation and land degradation for seeking new agricultural lands and firewood, as well as the unsustainable practices of plant or plant part sampling for medicinal values. Thus, public awareness needs to be raised among local communities and all other stakeholders on sustainable utilization and management of medicinal plant resources and the associated knowledge. On the top of that, ex-situ and in-situ conservation measures should be given particular attentions.
\end{abstract}

Keywords: Medicinal plants, indigenous knowledge, human ailment, Ethiopia

DOI: $10.7176 /$ PPAR/11-9-04

Publication date:May $31^{\text {st }} 2021$

\section{INTRODUCTION}

Ethno-botany is a broad term referring to the study of the relationship between people, plants and environment, embracing a wide range of disciplines (Martin 1995). Since the antique time plants have been an essential supply for treating and healing human and livestock ailments (Lulekal et al. 2008). Traditional remedies are the most important and sometimes the only source of therapeutics for nearly $80 \%$ of the Ethiopian population as well as is origin for $95 \%$ of traditional medicinal preparations (Bekele 2007). Ethiopia is rich in its plant biodiversity (Gemechu et al. 2015) that provides herbal remedies for tackling various kinds of human and livestock diseases (Giday et al. 2009).

In Ethiopia, cultivation and use of medicinal plants are commonly practiced for their affordability, acceptability, and accessibility (Seid and Tsegay 2011). There is large volume of expertise, skill and knowledge with therapeutic properties of plants, as traditional medicines, for treating both human and livestock ailments (Bekele 2007). Although most practices and treatments in herbal medicine require specialists or professionals, the herbalists, self-care using plants is common in Ethiopia. The promotion of traditional health practices together with modern health services becomes the most promising tool for ensuring affordable and sustainable heath care system, particularly for poor communities throughout developing countries (Hunde et al. 2006).

In Ethiopia, traditional medicinal plants and the associated knowledge have been deteriorating at an alarming rate (Bekele 2007). Natural and anthropologic factors become the underlying factors contributing to these losses, however, the threatening factors may vary from regions to regions (Teklehaymanot and Giday 2007). Previous studies on medicinal plants conducted in different parts of Ethiopia have documented the use of medicinal plants, associated knowledge and risk factors. Such studies have been conducted in Maale and Ari ethnic communities in southern Ethiopia (Kidane et al. 2014), in Tara -gedam and Amba remnant forests of Kemkem district (Chekole et al. 2015) and in Guba-lafto district in Northern Ethiopia (Chekole et al. 2015) and in Guduru district in western Ethiopia (Tadesse et al. 2018). Nevertheless, similar studies have not been conducted in the study areas although traditional medicine is widely practiced. Specifically, studies aiming at evaluating traditional medicinal plants used for treating human and livestock ailments is lacking. The local communities in the study areas have their own perception and skill of managing traditional plants and the associated indigenous knowledge and practices. These knowledge and practices have been accumulated over generations. Yet, increased population pressure and agricultural expansion activities might have caused shrinking of land and destruction of the plant biodiversity, with negative consequences not only on medicinal plants but also on the associated traditional knowledge. In addition, knowledgeable elders may die without sharing their knowledge to the younger generation. Therefore, the objective of this study is to document medicinal plants and associated traditional knowledge for treating human and livestock ailments in Raya Alamata District, Northern Ethiopia. The specific problems addressed in this study include identification of medicinal plants species used to treat both human and livestock ailments; documentation of the indigenous 
knowledge of local people on preparation, identification of plant parts used for medicinal purposes, route of administration of traditional medicine, and finding out local threats and conservation methods used by indigenous people to manage medicinal plants.

\section{MATERIALS AND METHODS}

\section{Description of the study area}

Raya Alamata District is located in the Southern zone of Tigray in Northern Ethiopia, bordered by Raya Azebo in the North, Ofla in the West, Amhara in the South and Afar in the East. It lies at $12^{\circ} 25^{\prime} \mathrm{N}$ and $39^{\circ} 33^{\prime} \mathrm{E}$ latitude and longitude. It is located at 600 kilometers North of Addis Ababa and is at about 180 kilometers south of the Tigray Regional Capital city, Mekele. The District has 15 Kebeles: Timuga, Selen Wuha, Limat, Selam Bekalisi, Kulu Gize Lemlem, Garjale, Tao, Laelay Dayu, Tsetsera, Merewa, Sorya, Akojira, Awid Kulu, Waja and Harle. The study was conducted in three Kebeles: Garjalle, Selen Wuha and Merewa (Figure 1). Based on the 2007 national census conducted by the Central Statistical Agency of Ethiopia (CSA), Raya Alamata has a total population of 80,840 . The number of male and female constitute 39,382 and 41,458, respectively. The altitude ranges from 1,361 to 3,171 m. a. s. 1. According to the National Meteorological Agency (NMA) (NMA 2018), the District receives from 600 to $700 \mathrm{~mm}$ annual rainfall and has from 23 to $27{ }^{\circ} \mathrm{C}$ annual temperature. The land size of the district is 75,502.14 hectares. About $23 \%$ of the District is divided into western highlands and $73 \%$ into eastern lowlands.

\section{Please insert Figure 1 here}

\section{Informant selection techniques}

The study kebeles were selected by simple random sampling of lottery method. Besides, a total of 18 key informants (seven from Garjalle, five from Selen Wuha and six from Merewa kebeles) from the age of 29 to 78 were interviewed. The key informants were selected purposively following Martin (1995) with the help and recommendation of Kebele administration leaders, elders, religious leaders and others who have information about traditional healers. This technique was used to engage healers who had no official permission for their traditional medicinal practices. Non-legalized healers do not officially register.

\section{Ethno - botanical data collection}

The ethno - botanical data was collected from April to May in 2019. Group discussions, key informant interviews, field observations, and guided field walks were used for data collection. Interview questions were prepared for the key informant interviews to collect data primarily on the medicinal plants used to treat different ailments, plant parts used, preparation methods of remedies, condition of preparation, administration routes and other uses than medicinal values. Data related to threats to traditional medicinal plants managements and the associated knowledge were also collected. Data on ailments treated, plant parts used, method of preparation of remedy, details of the administration, dosage, any noticeable side effects, and preservation techniques were collected from local communities, key informants, focus group discussants and field observations.

\section{Plant specimen collection and identification}

Sample specimens of medicinal plant species were collected from both wild and home gardens. They were then numbered, pressed and dried for identification. The identification of plants cited for their medicinal value was made both in the field and at the National Herbarium of Addis Ababa University. The identification of the plant specimens was done using different volumes of Flora of Ethiopia and Eritrea books and useful trees and shrubs of Ethiopia. Comparison for further identification was also carried out with authenticated specimens with the help of experts at the National Herbarium, experts from Agricultural Research Office of Raya Alamata and the Institute of Biodiversity and Conservation (IBC) of Ethiopia. Voucher specimens were kept in Hawassa University.

\section{Data analysis}

A descriptive statistical method, such as percentage and frequency, were employed to analyze and summarize data associated to sources of medicinal plants, method of preparation, routes of administration, conditions of preparation, plant parts, plant habits and associated knowledge. Following an earlier work (Heinrich et al. 1998) and with minor modification, the human ailments were grouped into seven categories. Accordingly, the collected data were analyzed using informant consensus factor and various ranking methods:

\section{Informant Consensus Factor (ICF)}

The ICF was calculated for each category depending on the consensus of informants on the reported cures for a group of ailments. The ICF was calculated as follows: number of use citation in each category (NUR) minus the 
number of species used (NT), divided by the numbers of use citations in each categories minus one (Alexiades 1996).

$I C F=N U R-N T / N U R-1$

Where, ICF=Informant Consensus Factor. NUR=Number of Use Citation NT=Number of Species

The informant consensus factor was calculated for each category. The informant consensus of medicinal plant use citations resulted in ICF ranging from 0.36 to 0.64 per illness category. A high value of ICF (close to 1 ) indicates that relatively few species are used by a large proportion of people, while a low value indicates that the informants disagree on the taxa to be used in the treatment within a category of illness.

\section{Priority ranking}

It is the simplest analytical tool for ethno-botanical studies. According to Martin (1995), priority ranking involves asking people to think of five to seven items and request to arrange those items according to a given criterion. Such criteria may be personal preference, perceived importance in the communities, or list of plant resources that people feel are becoming increasingly rare in their communal forests. Therefore, in this study a set of 5 plants were selected from the list of medicinal plants that were reported as scarce by most informants in the study area and presented to 6 key informants to rank according to their degree of scarcity. Each rank was given a numerical value of $(1,2,3$, and so on) with the most important items (most scarce medicinal plant species) given the highest value while the least important item was assigned 1 . Then, the number was summed and ranked.

\section{Direct matrix ranking}

Direct matrix ranking was done following Martin (1995) in order to compare multipurpose use of medicinal plants. Six multi - purpose medicinal plant species commonly reported by the informants were selected out of the total collected medicinal plants. Then, the use of these plants was listed for the key informants to rank them by considering six attributes: medicine, firewood, charcoal, construction, food and fence. The listed plant species were provided to six key informants to give value according to their use for a particular attribute. The scores were given to each attribute, and ranked to compare the use values of the reported plant species. Then, each chosen key informant was asked to assign attribute of each species $(5=$ most valuable, $4=$ very good, $3=$ good, $2=$ less used, $1=$ least valuable, and $0=$ not used). The values of each species were finally summed up and ranked.

\section{Paired comparison}

Paired comparison is used to understand the degree of preferences or levels of importance of certain selected medicinal plants/parts of plants used. A pair of selected plant specimens with all possible combinations were presented to selected respondents and their responses were recorded. To this effect, six key informants were used to show the efficacy and status of five medicinal plants species to treat external wound. Finally, scores of each species were summed up and ranked based on the preference of the six key informants against the external wound. In paired-wise ranking, relatively few items are included; because the time needed to carry out the task increases exponentially as additional items are included and the total number of pairs required increases as shown by the value of $n(n-1) / 2$ where ' $n$ ' stands for number of items to be compared (Martin 1995).

\section{Ranking of threats to medicinal plants}

Ranking of threats to medicinal plants, which were reported by most of the informants in the study area, was conducted using six selected key informants as described by Martin (1995). As mentioned by most of the informants, six threats were selected and the informants were asked to give six for the most threatening factor and one for the least threatening factor. This information was used to determine the highest threatening factor to traditional medicinal plants in the study area and to suggest the necessary appropriate conservation measures.

\section{RESULTS AND DISCUSSION}

\section{Source and willingness to share traditional medicinal knowledge}

Family was the major source of traditional medicinal knowledge in the study district. Accounting for $66.67 \%$ of the in formants, fathers were the major source of traditional medicinal knowledge (Table 1).

\section{Please insert Table 1 here}

The local people were willing to share and transfer their traditional medicinal knowledge to their family 
members. The tendency to share their traditional medicinal knowledge was highest with trusted eldest son $(50 \%)$, followed by trusted son $(27.78 \%)$ (Table 2$)$. This is because traditional medical practitioners want their knowledge to be kept secret. Previous studies indicated that traditional health practitioners believe traditional medicine is effective when kept within family members by Abdurhman (2010) and Tefera and Yihune (2019). When the first son is untrustworthy in keeping the secrecy of the knowledge, parents transfer their traditional knowledge to their second son (Table 2).

\section{Please insert Table 2 here}

\section{Composition of medicinal plant species}

A total of 47 plant species, with their medicinal use value, were recorded, distributing among 31 families and 44 genera (Appendix 1). In term of species composition, Fabaceae, Solanaceae, Euphorbiaceae, Asteraceae, Oleaceae, Cucurbitaceae and Rhamnaceae (Figure 5) were the most frequently cited families in the study district. The rest of the species were belonged to one family each. A total of 33 medicinal plants were found to be used for treating human ailments (Appendix 2), six for livestock ailments (Appendix 3) and eight for both human and livestock ailments (Appendix 1). On top of that, the plants were found to treat 35 different health problems, affecting 27 human and eight livestock ailments (Appendix 1). Among the families cited, Fabaceae was the leading medicinal family, consisting of nine medicinal plants, followed by Solanaceae composing four medicinal plants. Megersa et al. (2013) reported Fabaceae to be the leading family, followed by Solanaceae with eight species in central Ethiopia and Regassa (2013) also reported Fabaceae to be the leading family with five medicinal species in Southern Ethiopia.

\section{Please insert Figure 2 here}

\section{Spatial distribution of medicinal plants}

Regarding the distribution of medicinal plants, out of the 47 plant species, $53.19 \%$ of them were grown in the wild while $29.79 \%$ were domesticated and cultivated around homestead, while $17.06 \%$ were grown in the semiwild areas (Figure 3). Except for the cultivated and weedy species of medicinal plants, long distance walks were required to collect samples ascribing to their limited occurrence. The sources of the medicinal plants were mainly the wild vegetation that accounted $53.19 \%$, followed by cultivated ones, accounting $29.79 \%$. This indicates that the majority of the medicinal plants grew in the wild vegetation. This result agrees with a finding from Mesfin et al. (2014) in Southern Ethiopia and Tilahun (2018) in Northern Ethiopia where the majority of medicinal plants were collected from the wild, accounting for $77 \%$ and $76.98 \%$, respectively. A few others were collected from home gardens. This is because the practice of cultivation of plants for their medicinal purpose around home gardens is low. Communities in the study area made less effort to cultivate medicinal plants in their home gardens. They rather went to the nearby wild vegetation or distant places for harvesting.

\section{Please insert Figure 3 here}

\section{Habits of medicinal plants}

Out of the total 47 medicinal plants collected, herbs comprised $46.81 \%$, shrubs $27.66 \%$, trees $21.27 \%$ and climber comprised $4.26 \%$ (Figure 4). Herbs and shrubs are widely used, which might owe to the relatively higher abundance of those species in the study area. Teklay et al. (2013) found herbs to be the most utilized plants, accounting for $44 \%$ of the species, followed by shrubs $29 \%$ in Northern Ethiopia. Enyew et al. (2014) also found that herbs were the most widely used, accounting for $43.87 \%$, followed by shrubs that accounted for $35.84 \%$ in Central Ethiopia.

\section{Please insert Figure 4 here}

\section{Plant parts used for medicine}

Of the total medicinal plant parts, leaves $(41.94 \%)$ and roots $(20.97 \%)$ were the most commonly used plant parts in the preparation of remedies. This was pursued by seeds $(12.9 \%)$ and fruits $(12.90 \%)$ as well as bulbs $(4.48 \%)$, latex $(4.48 \%)$ and bark (1.61\%) (Figure 5). The popularity of roots next to leaves might be due to the simplicity in using and preparing remedies out of them, such as chewing or inhalation after heating with fire. Roots can be also dried and powdered or homogenized with water. Utilization of leaves for drug preparation may not cause detrimental effect on the plants compared to utilization of roots. Thus, the use of leaves better helps sustainable harvesting and management of plants. Kidane et al. (2018) reported that leaves (38.62\%) were the most commonly used medicinal plant parts, followed by roots $(17.06 \%)$ in Northern Ethiopia. 
Please insert Figure 5 here

\section{Mode of preparation, route of administration, dosage and side effects}

The highest mode of preparation was pounding (32.26\%), pursued by crushing $(27.42 \%)$, chewing $(12.91 \%)$, powder form (11.29\%), roasted smoke (8.06\%), unprocessed (4.84\%) and in the form of juice (3.22\%) (Figure 6). This may be due to the possibility of effective extraction of plant ingredients when pounding, crushing and chewing for enhancing their curative potential. This is in agreement with a finding from a study conducted in central Ethiopia by Tadesse et al. (2018) that the highest traditional medicines were prepared by pounding (33.3\%), followed by crushing (24.6\%). The most popular route of administration was dermal $(43.55 \%)$, succeeded by oral (38.71\%), fumigation $(9.68 \%)$, eye $(4.84 \%)$ and the least is nasal $(3.22 \%)$. This report agrees with reports from similar studies conducted in Southern Ethiopia by Giday et al. (2009) that the highest route of administration was dermal (39\%), pursued by oral (33\%).

About $24.14 \%$ of the remedies were mixed with water, butter, honey and coffee while the remaining were used without addition of any ingredients (Table 3). Moreover, there was no standardized measure of dosage of herbal remedies in the study area. Coffee cup, tine, finger line, teaspoon, tea glass, and the number of powder droplets picked by two finger tips were used for dosage determinations. Thus, lack of precision and standardization is one of the drawbacks for the recognition of traditional health care system. Medicines prepared from Allium sativum, Aloe megalacantha, Olea europea, Ocimum lamiifolium and Euphorbia abyssinica were reported to have burning sensation, bitter taste, vomiting and sweating. Some side effects were understood as an indication for the functioning of the herbal medicine. The healers also made different dosages of traditional medicines based on differences in gender, age, physical condition and appearance among patients by using their experiences. The lack of standardized unit of measurements of the plant remedies means that same types of medicinal remedies for the same types of ailments might be given with different dosages in the same or different Kebeles of the study District. Lack of precision and standardization were the major drawbacks for the recognition of traditional health care system. This agrees with Chekole (2017) in Northern Ethiopia who indicated that lack of precision and standardization was the major drawbacks for the recognition traditional health care system. This finding is also similar with a finding from a study conducted by Megersa et al. (2013) in central Ethiopia. Based on the information gathered from the key informants, taking over dosage or under dosage are common health problems.

\section{Please insert Figure 6 here}

\section{Please insert Table 3 here}

\section{Methods of preservation of the remedies and storage methods}

The majority of the remedies was prepared from fresh parts of medicinal plants $(46.77 \%)$, pursued by fresh and dry form $(30.65 \%)$, while the remaining $(22.58 \%)$ were in the form of dry (Figure 7$)$. Water is the most frequently used solvent in remedy preparation. Coffee and butter were also used as solvents or additives in the preparation of remedies. Healers stored the collected traditional plant medicines in their homes for further usage, mostly in powdered and raw dried forms. In this regard, clothes and plastic bags were used mainly to store dried medicines. However, the preferences of fresh plant parts for medicine were higher than dried ones. Based on the information gathered from key informants, the highest method of preservation was fresh (46.77\%), followed by fresh/dry $(30.65 \%)$. In contrast, some traditional healers store dried plant medicines in different kinds of containers in their homes. This is in agreement with the work of Gebrehiwot (2010) that the highest condition of preparation was from fresh material $(49.68 \%)$, followed by fresh/dry $(35.48 \%)$ in Oromia Region of Ethiopia. The main reason for the preference of fresh plants over dried ones may be due to the presence of better biologically active chemicals in fresh leaves that would deteriorate with drying.

\section{Please insert Figure 7 here}

\section{Informant consensus}

Application of informant consensus analysis showed that some medicinal plants are more popular than the others. Informant consensus value gives good indication about a particular species that serves a particular health problem or specific medicinal plants serving several health problems. Accordingly, Ocimum lamiifolium was cited by $44.44 \%$ of the informants, followed by Datura stramonium that was cited by $38.89 \%$ of the informants (Table 4). The informant consensus indicated that some medicinal plant species are more popular than others. Such information underscores the pharmacological significance of medicinal plants in the study area. Ocimum lamiifolium, Datura stranomium and Acacia etbaica were the three most cited medicinal plant species in the study area. Besides, wound, tonsillitis and abdominal pain were the most cited ailments in Northern Ethiopia. 
According to Kefalew et al. (2015) medicinal plants with higher informant consensus need to be seriously considered for further ethno-pharmacological studies because they are the species that are widely applied by many people and are utilized for a long period.

\section{Please insert Table 4 here}

\section{Informant Consensus Factor (ICF)}

The most frequently occurring human diseases were grouped into different categories based on the site of occurrence of disease, severity of disease and prevalence of the disease among the local people. The informant consensus factor was calculated for each category. The ICF of medicinal plant usage result ranged from 0.36 to 0.64 per illness category (Table 5). Some of the categories of diseases had high ICF than the other categories. Plants used against disease categories related to abdominal pain, dermal and respiratory had high ICF in the study area. A high value of ICF (close to 1) indicates that relatively few species are used by a large number of population, while a low ICF value indicates informants' disagreement on the taxa to be used for the treatment of a particular category of illness. Similar findings were reported earlier: Teklehaymanot and Giday (2007) by people in Northwestern Ethiopia, Abebe (2011) in Amhara Region of Ethiopia and Kefalew et al. (2015) in central Ethiopia.

\section{Please insert Table 5 here}

\section{Priority ranking of medicinal plants}

Priority ranking of five medicinal plants based on the degree of vulnerability or availability in the study area was conducted using 6 key informants. Olea europea is the most threatened medicinal plant species in the study area, followed by Acacia etbaica and Calpumia aurea (Table 6). The result from preference ranking showed a particular medicinal plant is more preferred by the local people based on given criteria. Preference ranking was made in Ethiopia by many authors to see the choice of the local people: Tora and Heliso (2017) in Southern Ethiopia and Kidane et al. (2014) in Southern Ethiopia.

\section{Please insert Table 6 here}

\section{Direct matrix ranking}

Direct matrix ranking was performed to assess the relative importance of plants. The direct matrix ranking showed that Balanite aegyptiea stood first in being the most multipurpose medicinal plant, followed by Olea europea, whereas Euphorbia abyssinica was the least (Table 7). This result indicated that Balanitea egyptiea and Olea europea appear to have more provision than the others as they are used for multiple purposes. Other than medicinal uses, medicinal plants of the study area were found to serve other purposes. The key informants identified five medicinal plant species that were used by the local communities for other purposes, such as firewood, charcoal, construction, fencing and food. Direct matrix ranking was made in Ethiopia by many authors to see the multiple purposes to be offered by medicinal plants: Ayalew et al. (2017) in Eastern Ethiopia, Tadesse et al. (2018) in central Ethiopia and Kidane et al. (2018) in northern Ethiopia.

\section{Please insert Table 7 here}

\section{Paired comparison}

Paired comparison was made to determine the most preferred medicinal plants among the five species that were used to treat external wound in the study area. The responses from key informants showed that Aloe megalacantha ranked first, followed by Heliotropium steudneri (Table 8). Therefore, Aloe megalacantha becomes the most favored while Allium sativum becomes the least favored over the other plant species cited in treating external wound in the study area. Pairwise ranking of medicinal plants treating particular ailments showed that some medicinal plants are more preferable than the others. Such ranking of medicinal plants treating external wound showed that Aloe megalacantha become the most preferable plant species. This showed that the preference of plant species against ailments varies from person to person. The most favored species are usually the most efficacious. A few pair wise ranking studies made in Ethiopia made their choice on individual basis such as Chekole (2017) in Northern Ethiopia and Tadesse et al. (2018) in central Ethiopia.

\section{Please insert Table 8 here}

\section{Availability and status of medicinal plants}

The availability of medicinal plant species in the study District was mostly season dependent. Generally, the 
availability of them was moderate. Especially herbs were relatively more abundant in rainy season compared to dry season. As to the status of medicinal plants, out of the 47 plants species, $46.81 \%$ were reported to be medium, $27.66 \%$ were rare, while $25.53 \%$ were common in the dry season (Figure 8 ). Similar finding was reported by Tadesse et al. (2018) having medium status as the highest (59.56\%) in central Ethiopia.

\section{Please insert Figure 8 here}

\section{Documentation, collaboration, degree of acceptance and effect of modernization on traditional medicinal practice}

All of the key informants did not document any traditional medicinal practice. They rather transfer ethnobotanical knowledge mainly through oral tradition. They are less likely interested to collaborate with other knowledgeable people and traditional healers.

Most of the key informants witnessed that most of the local people are interested to use herbal medicines. Effectiveness, cheapness and accessibility are the major reasons for their preference as herbal medicine. However, the tendency of the local people to be treated by herbal medicine has been declining from time to time. Furthermore, the information gained from key informants and group discussants witnessed that modernization (including the expansion of education, health service such as clinics, health posts and western cultural influence) have negatively influenced the use of herbal medicines and the associated knowledge. According to Giday et al. (2009) in Southern Ethiopia, the immediate and severe threat to the local medical practice and knowledge arise from an increasing influence of modernization such as increase of modern education, industrialization, changes in life style and migration from rural to urban area. To curb this tendency, awareness has to be enhanced through different means among local communities especially young generation, such as health workers, school clubs and mini media need to teach about the usefulness of the knowledge and practice of traditional medicinal plants. Most young people showed a tendency of ignoring traditional medical practice (Giday et al. 2009).

The indigenous knowledge of plant medicines is kept secret to a few practitioners. According to the information gathered from the informants, the majority of professional traditional healers never show medicinal plants and share their traditional knowledge freely to anybody. They, however, share their knowledge of medicinal plants to one or in some cases to their family members who they trust most when they get aged. They always assert the receiver of the knowledge to follow the same principles of keeping secrecy. Practitioners keep the confidentiality of their knowledge for a couple of reasons: maintaining the healing power of plant remedies and as means of income for practitioners. It was reported that $80 \%$ of Ethiopian population depend on traditional medicine for their primary health care system (Bekele 2007). The plant parts used and methods of preparation are often closely guarded secrets. Similar findings were reported: Giday and Ameni (2003) in Northern Ethiopia, Abdurhman (2010) in Northern Ethiopia and Yirga and Zeraburk (2011) in Western Ethiopia. Furthermore, valuable information can be lost whenever a medicinal plant is lost or when a traditional medical practitioner dies without passing his/her indigenous knowledge to others. Similar findings were reported elsewhere, such as Flatie et al. (2009) in Western Ethiopia, Megersa et al. (2013) in Western Ethiopia and Leul Kidane et al (2018) in Northern Ethiopia.

Group discussants informed that some traditional medicinal plants were becoming scarce from time to time due to natural and anthropogenic factors. Sometimes, it was difficult to find some medicinal plants during the dry season especially herbs. Furthermore, the knowledge on traditional medicinal plants particularly of the young generation, seems to decline from time to time. The causes are the expansion of health posts, health care centers, and the growth of health workers, which depend on modern healthcare system than traditional medicine. Thus, modernization encourages the young generation to avert the use of traditional herbal medicine. Group discussants also confirmed that trees and shrubs have been heavily exploited as a result of agricultural expansion, such as collection of forest resources for firewood, construction, and cleaning forest lands for agricultural lands, and other purposes. In general, key informants indicated that local communities use traditional medicinal plants to treat both human and livestock health problems.

Observations from guided field walk indicated that most of the local people use traditional medicine for treating different type of ailments of both human and livestock. The most common health problems mentioned were dermal diseases, abdominal pain, respiratory diseases, leech and many others.

\section{Factors threatening medicinal plants and conservation practices}

Drought, agricultural activities for new agricultural lands, firewood, charcoal, construction and urbanization were the major factors affecting the medicinal plants. Among these factors, agricultural activities for new agricultural land expansion was ranked first by the selected key informants, pursued by drought and firewood collection (Table 9). Nearly all key informants and group discussants were familiar with threats, which have caused scarcity of medicinal plants. This information can be used to manage threats to medicinal plants and to suggest appropriate conservation measures. Similar findings were reported from different parts of the country, 
such as Lulekal et al. (2008) that the main threats to the survival of medicinal plants in Oromia Region were agricultural expansion and drought. These anthropogenic and natural factors coupled with very poor conservation efforts threatened medicinal plants survival in the study area. Amsalu (2010) in Amhara Region of Ethiopia and Mesfin et al. (2014) in Southern Ethiopia also reported similar results. The study also revealed that the type and degree of threats vary from species to species in the study area. In this regard, medicinal plant species such as Acacia etbaica, Olea europia and Calpumia aurea become the most vulnerable medicinal species. In addition, improper management of plant resources, such as harvesting roots of medicinal plants is a significant threat to medicinal plants. In this regard, roots were the second major plant parts $(20.97 \%)$ of the medicinal plant species to treat ailments.

\section{Please insert Table 8 here}

Many of the key informants with traditional medicine knowledge give priority to the immediate use of the medicinal plants than to the sustainable uses. The anthropogenic and natural threats to the biodiversity, in one or another form, have caused scarcity of medicinal plants. As a result, medicinal plants especially growing in the wild and with high curative power were hardly available. Thus, practioners walk long distance to collect them. Key informants and group discussants indicated that there is only limited effort made by the community to conserve medicinal plants. Nevertheless, protected areas for seasonal grazing and spiritual purposes have helped the conservation of medicinal plants. A few places are, however, protected for their spiritual and cultural purposes. These places are ideal sites for conservation of medicinal plants as cutting and harvesting of plants or plant parts are prohibited. A few medicinal plant species, such as Allium sativum, Cicer arietinum and Lycopersican esculentum, are cultivated in or around homestead. This is good practice for the conservation of medicinal plants. Field observations and group discussions witnessed that many of the plants growing near home gardens are mainly cultivated for other purposes, such as food and spices. Yet, species like Artemisia absinthim are cultivated for their medicinal value as well. Similar finding was reported by Chekole et al. (2015) in Northern Ethiopia.

\section{CONCLUSIONS}

A total of 47 species of medicinal plants belonging to 44 genera and 31 families were recorded. Fabaceae $(9$ species) was represented by the highest number plant species, followed by Solanaceae (4 species). Herbs $(46.81 \%)$ were the dominant growth habits, followed by shrubs $(27.66 \%)$. Leaves $(41.94 \%)$ were the dominant plant parts used in the preparation of remedies, followed by roots $(20.97 \%)$. The most common method of remedy preparation was pounding $(32.26 \%)$, followed by crushing $(27.42 \%)$. Dermal $(43.55 \%)$ was the major route of administration, followed by oral (38.71\%). Most herbal remedies were prepared and preserved from fresh materials (46.77\%), followed by fresh/dried plant materials $(30.65 \%)$. Of the 47 species of medicinal plants, $70.21 \%$ were cited to treat human ailments, while $12.77 \%$ species were used to treat livestock ailments and $17.02 \%$ species were used to treat both livestock and human ailments. In terms of abundance, wild habitat $(53.19 \%)$ was the major source of medicinal plant species, followed by cultivation $(29.79 \%)$. The use of herbs as the major source of medicinal purpose than trees and shrubs might help to ensure the survival of shrubs and trees. Though wild habitats are the major source of medicinal plants, they are subjected to the loss of a number of plant species due to different anthropogenic and natural factors such as agricultural activities for new lands, drought, firewood and others. With regard to the dosage of traditional medicinal plants, there is no standardized unit of measurement. This might have negative consequence on the health of the society. On other hand, there is encumbrance in the transfer of knowledge from the elders to the young generation. The major hindrance in this regard might attribute to the introduction of modern education and culture. An effort made by the communities to conserve medicinal plants is unsatisfactory though there are efforts in cultivating medicinal plants around homesteads. Thus, Ex-situ and In-situ conservation measures should be taken to protect medicinal plants from further destruction and special attention should be given to the medicinal plants that were indicated by priority ranking exercise as the most threatened ones.

\section{Acknowledgements}

The Graduate School of Hawassa University, Ethiopia, funded this research. The agricultural extension workers, traditional medicine practitioner, experts and farmers are grateful for their unreserved assistance during the data collection. They provided useful insights and assistance to the researchers. The district agriculture and rural offices are also thanked for their generous hospitality and support.

\section{Declarations:}

Ethics approval and consent to participate

Not applicable 


\section{Consent for publication}

Not applicable

\section{Availability of data and material}

Plant specimens were deposited in the Department of Biology, Hawassa University, Ethiopia. Furthermore, the authors declare that sequencing data of 47 species identified supporting the findings of this study are available within the article and its supplementary information files as appendix.

\section{Competing interests}

The author declares that there are no competing interests.

\section{Authors' contributions}

Both authors were involved in data collection and writing of the manuscript. Both authors read and approved the final manuscript for submission and publication.

\section{REFERENCES}

Abdurhman N (2010) Ethnobotanical Study of Medicinal Plants Used by Local People in Ofla Wereda, Southern Zone of Tigray Region, Ethiopia. Addis Ababa University

Abebe E (2011) Ethnobotanical Study on Medicinal Plants Used by Local Communities in Debark Wereda, North Gondar Zone, Amhara Regional State, Ethiopia [M. Sc. thesis] Addis Ababa University

Alexiades MN (1996) Collecting ethnobotanical data: an introduction to basic concepts and techniques Advances in Economic Botany 10:53-94

Amsalu N (2010) An Ethno botanical Study of Medicinal Plants in Farta Wereda, South Gonder Zone of Amhara Region Ethiopia. Addis Ababa University

Ayalew S, Kebede A, Mesfin A, Mulualem G (2017) Ethnobotanical study of medicinal plants used by agro pastoralist Somali people for the management of human ailments in Jeldesa Cluster, Dire Dawa Administration, Eastern Ethiopia Journal of Medicinal Plants Research 11:171-187

Bekele E (2007) Study on Actual Situation of Medicinal Plants in Ethiopia. Prepared for Japan Association for International Collaboration of Agriculture and Forestry, 'Addis Ababa, Ethiopia

Chekole G (2017) Ethnobotanical study of medicinal plants used against human ailments in Gubalafto District, Northern Ethiopia Journal of ethnobiology and ethnomedicine 13:55

Chekole G, Asfaw Z, Kelbessa E (2015) Ethnobotanical study of medicinal plants in the environs of Tara-gedam and Amba remnant forests of Libo Kemkem District, northwest Ethiopia Journal of ethnobiology and ethnomedicine 11:4

Cunningham AB (1996) People, park and plant use: Recommendations for multiple-use zones and development alternatives around Bwindi Impenetrable National Park, Uganda People, park and plant use: Recommendations for multiple-use zones and development alternatives around Bwindi Impenetrable National Park, Uganda

Elujoba AA, Odeleye O, Ogunyemi C (2005) Traditional Medicine Development for Medical and Dental Primary Health Care Delivery System in Africa African journal of traditional, complementary and alternative medicines 2:46-61

Enyew A, Asfaw Z, Kelbessa E, Nagappan R (2014) Ethnobotanical study of traditional medicinal plants in and around Fiche District, Central Ethiopia Current Research Journal of Biological Sciences 6:154-167

Flatie T, Gedif T, Asres K, Gebre-Mariam T (2009) Ethnomedical survey of Berta ethnic group Assosa Zone, Benishangul-Gumuz regional state, mid-west Ethiopia Journal of Ethnobiology and Ethnomedicine 5:14

Gebrehiwot M (2010) An ethnobotanical study of medicinal plants in Seru wereda, Arsi Zone of Oromia Region, Ethiopia. Addis Ababa University

Gemechu T, Soromessa T, Kelbessa E (2015) Structure and regeneration of Gendo moist montane forest, East Wellega Zone, Western Ethiopia J Environ Earth Sci 5:15

Giday M, Ameni G (2003) An ethnobotanical survey of plants of veterinary importance in two woredas of southern Tigray, Northern Ethiopia SINET: Ethiopian Journal of Science 26:123-136

Giday M, Asfaw Z, Woldu Z, Teklehaymanot T (2009) Medicinal plant knowledge of the Bench ethnic group of Ethiopia: an ethnobotanical investigation Journal of Ethnobiology and Ethnomedicine 5:34

Heinrich M, Ankli A, Frei B, Weimann C, Sticher O (1998) Medicinal plants in Mexico: Healers' consensus and cultural importance Social Science \& Medicine 47:1859-1871

Hunde D, Asfaw Z, Kelbessa E (2006) Use of traditional medicinal plants by people of 'Boosat'sub district, central eastern Ethiopia Ethiopian Journal of Health Sciences 16

Kefalew A, Asfaw Z, Kelbessa E (2015) Ethnobotany of medicinal plants in Ada'a District, East Shewa Zone of Oromia regional state, Ethiopia Journal of ethnobiology and ethnomedicine 11:25

Kidane B, van Andel T, van der Maesen LJG, Asfaw Z (2014) Use and management of traditional medicinal plants by Maale and Ari ethnic communities in southern Ethiopia Journal of ethnobiology and ethnomedicine 10:46 
Kidane L, Gebremedhin G, Beyene T (2018) Ethnobotanical study of medicinal plants in Ganta Afeshum District, Eastern Zone of Tigray, Northern Ethiopia Journal of ethnobiology and ethnomedicine 14:64

Lulekal E, Kelbessa E, Bekele T, Yineger H (2008) An ethnobotanical study of medicinal plants in Mana Angetu District, southeastern Ethiopia Journal of ethnobiology and Ethnomedicine 4:10

Martin G (1995) Ethnobotany; a method Manual Chap mart and Hall. London: Earthscan publications,

Megersa M, Asfaw Z, Kelbessa E, Beyene A, Woldeab B (2013) An ethnobotanical study of medicinal plants in Wayu Tuka district, east Welega zone of oromia regional state, West Ethiopia Journal of ethnobiology and ethnomedicine 9:68

Mesfin F, Seta T, Assefa A (2014) An ethnobotanical study of medicinal plants in Amaro Woreda, Ethiopia Ethnobotany Research and Applications 12:341-354

NMA (2018) National Meteorological Agency (NMA), Mekelle (Tigray), Ethiopia.

Regassa R (2013) Assessment of indigenous knowledge of medicinal plant practice and mode of service delivery in Hawassa city, southern Ethiopia Journal of Medicinal Plants Research 7:517-535

Seid MA, Tsegay BA (2011) Ethnobotanical survey of traditional medicinal plants in Tehuledere district, South Wollo, Ethiopia Journal of Medicinal Plants Research 5:6233-6242

Tadesse A, Kagnew B, Kebede F (2018) Ethnobotanical study of medicinal plants used to treat human ailment in Guduru District of Oromia Regional State, Ethiopia Journal of Pharmacognosy and Phytotherapy 10:64-75

Tefera T, Yihune M (2019) Ethnobotanical study on medicinal plants used by indigenous people in Tenta District, South Wollo, Ethiopia

Teklay A, Abera B, Giday M (2013) An ethnobotanical study of medicinal plants used in Kilte Awulaelo District, Tigray Region of Ethiopia Journal of ethnobiology and ethnomedicine 9:65

Teklehaymanot T, Giday M (2007) Ethnobotanical study of medicinal plants used by people in Zegie Peninsula, Northwestern Ethiopia Journal of ethnobiology and Ethnomedicine 3:12

Tilahun Y (2018) Ethnobotanical study of traditional medicinal plants used in and around Adigrat town, eastern Tigray, Ethiopia Journal of Medicinal Plants 6:11-19

Tora A, Heliso T (2017) Assessment of the indigenous knowledge and use of traditional medicinal plants in Wolaita zone, Southern Ethiopia Int J Med Plants Nat Prod 3:16-22

Wondimu T, Asfaw Z, Kelbessa E (2007) Ethnobotanical study of medicinal plants around 'Dheeraa'town, Arsi Zone, Ethiopia Journal of Ethnopharmacology 112:152-161

Yirga G, Zeraburk S (2011) Ethnobotanical study of traditional medicinal plants in Gindeberet District, western Ethiopia Mediterr J Soc Sci 2:49-54

Table 1: Knowledge source on the use of traditional medicinal plants

\begin{tabular}{llll}
\hline Source of knowledge & No. of informants & Percentage (\%) & Rank \\
\hline Father & 12 & 66.66 & $1^{\text {st }}$ \\
Mother & 3 & 16.66 & $2^{\text {nd }}$ \\
Friends & 1 & 5.56 & $3^{\text {rd }}$ \\
Father and mother & 1 & 5.56 & $3^{\text {rd }}$ \\
Brother or sister & 1 & 5.56 & $3^{\text {rd }}$ \\
\hline Total & $\mathbf{1 8}$ & $\mathbf{1 0 0}$ & \\
\hline
\end{tabular}

Table 2: Willingness to share knowledge of traditional medicinal plants

\begin{tabular}{llll}
\hline Willingness to share knowledge & No. of informants & Percentage (\%) & Rank \\
\hline Trusted eldest son & 9 & 50.00 & $1^{\text {st }}$ \\
Trusted son & 5 & 27.78 & $2^{\text {nd }}$ \\
All members of the family & 2 & 11.10 & $3^{\text {rd }}$ \\
Relatives & 1 & 5.56 & $4^{\text {th }}$ \\
Friends & 1 & 5.56 & $4^{\text {th }}$ \\
\hline Total & $\mathbf{1 8}$ & $\mathbf{1 0 0}$ & \\
\hline
\end{tabular}


Table 3: Route of administration of traditional medicine

\begin{tabular}{lll}
\hline Route of administration & No. of plant parts & Percentage (\%) \\
\hline Dermal & 27 & 43.55 \\
Oral & 24 & 38.71 \\
Fumigation & 6 & 9.68 \\
Eye & 3 & 4.48 \\
Nasal & 2 & 3.2 \\
\hline Total & $\mathbf{6 2}$ & $\mathbf{1 0 0}$ \\
\hline
\end{tabular}

Table 4: Informant consensus of medicinal plants used for the treatment of human ailments in study area

\begin{tabular}{llll}
\hline Scientific name & No. of informants cited & Percentage (\%) & Rank \\
\hline Ocimum lamiifolium & 8 & 44.44 & $1^{\text {st }}$ \\
Datura stramonium & 7 & 38.89 & $2^{\text {nd }}$ \\
Acacia etbaica & 5 & 27.78 & $3^{\text {rd }}$ \\
Allium sativum & 4 & 22.22 & $4^{\text {th }}$ \\
Heliotropium steudneri & 3 & 16.67 & $5^{\text {th }}$ \\
\hline
\end{tabular}

Table 5: Informant consensus factor of human diseases

\begin{tabular}{llll}
\hline Disease category & Species & Use citation & ICF \\
\hline Respiratory diseases (asthmatic reaction, cough, tonsillitis) & 8 & 19 & 0.61 \\
Dermal diseases (wound, measles and skin diseases) & 13 & 34 & 0.63 \\
Headache, hypertension, malaria, tooth ache & 7 & 11 & 0.4 \\
Bone fracture, abortion & 8 & 13 & 0.42 \\
General diseases (tension, evil eye and evil sprits & 8 & 12 & 0.36 \\
Eye and nail problem & 5 & 11 & 0.6 \\
Abdominal pain, tape worm, jaundice and amoeba & 7 & 18 & 0.64 \\
\hline
\end{tabular}

Table 6: Priority ranking of threatened medicinal plants

\begin{tabular}{|c|c|c|c|c|c|c|c|c|c|}
\hline \multirow[t]{2}{*}{ No } & \multirow[t]{2}{*}{ Plant species } & \multicolumn{6}{|c|}{ Respondents' ranking } & \multirow[b]{2}{*}{ Total } & \multirow[b]{2}{*}{ Rank } \\
\hline & & $\mathbf{R}_{1}$ & $\mathbf{R}_{2}$ & $\mathbf{R}_{\mathbf{3}}$ & $\mathbf{R}_{4}$ & $\mathbf{R}_{5}$ & $\mathbf{R}_{6}$ & & \\
\hline 1. & Heliotropium steudneri & 2 & 3 & 2 & 2 & 3 & 1 & 13 & $4^{\text {th }}$ \\
\hline 2 & Acacia etbaica & 4 & 5 & 4 & 4 & 4 & 5 & 26 & $2^{\text {nd }}$ \\
\hline 3 & Calpumia aurea & 3 & 1 & 3 & 3 & 1 & 3 & 14 & $3^{\text {rd }}$ \\
\hline 4 & Ocimum lamiifolium & 1 & 2 & 1 & 1 & 2 & 2 & 9 & $5^{\text {th }}$ \\
\hline 5 & Olea europea & 5 & 4 & 5 & 5 & 5 & 4 & 28 & $1^{\text {st }}$ \\
\hline
\end{tabular}

*Key: where R represented respondents

Table 7: Direct matrix ranking of multiple uses of medicinal plants

\begin{tabular}{|c|c|c|c|c|c|c|c|c|}
\hline \multirow[t]{2}{*}{ Plant species } & \multicolumn{8}{|c|}{ Use category } \\
\hline & Medicine & Firewood & Charcoal & Building & Food & Fence & Total & Rank \\
\hline Olea europea & 2 & 4 & 3 & 5 & 0 & 4 & 18 & $2^{\text {nd }}$ \\
\hline Acacia etbaica & 2 & 4 & 3 & 5 & 0 & 3 & 17 & $3^{\text {rd }}$ \\
\hline $\begin{array}{l}\text { Eucalyptus } \\
\quad \text { camaldulers }\end{array}$ & 2 & 5 & 1 & 5 & 0 & 3 & 16 & $4^{\text {th }}$ \\
\hline Opuntia ficus & 2 & 0 & 0 & 0 & 5 & 5 & 12 & $6^{\text {th }}$ \\
\hline Balanite aegyptiea & 2 & 4 & 3 & 4 & 3 & 4 & 20 & $1^{\text {st }}$ \\
\hline Acacia abyssinica & 0 & 4 & 4 & 4 & 0 & 3 & 15 & $5^{\text {th }}$ \\
\hline
\end{tabular}

Table 8: Paired comparison of five medicinal plant species used to treat external wound

\begin{tabular}{|c|c|c|c|c|c|c|c|c|}
\hline \multirow[t]{2}{*}{ Plant species } & \multicolumn{6}{|c|}{ Respondents levelled } & \multirow[t]{2}{*}{ Total } & \multirow[t]{2}{*}{ Rank } \\
\hline & $\mathbf{R}_{1}$ & $\mathbf{R}_{2}$ & $\mathbf{R}_{3}$ & $\mathbf{R}_{4}$ & $\mathbf{R}_{5}$ & $\mathbf{R}_{6}$ & & \\
\hline Aloe megalacantha & 4 & 1 & 2 & 3 & 2 & 4 & 16 & $1^{\text {st }}$ \\
\hline Allium sativum & 2 & 1 & 0 & 1 & 3 & 0 & 7 & $5^{\text {th }}$ \\
\hline Hibiscus micranthus & 1 & 2 & 2 & 2 & 3 & 1 & 11 & $4^{\text {th }}$ \\
\hline Heliotropium steudneri & 1 & 4 & 4 & 2 & 0 & 3 & 14 & $2^{\text {nd }}$ \\
\hline Datura stramonium & 2 & 2 & 2 & 2 & 2 & 2 & 12 & $3^{\text {rd }}$ \\
\hline
\end{tabular}

*Key: where $\mathrm{R}$ represented respondents 
Table 9: Ranking of threats to medicinal plants

\begin{tabular}{lllllllll}
\hline Threat & \multicolumn{7}{c}{ Respondent's ranking } \\
\cline { 2 - 8 } & $\mathbf{R}_{\mathbf{1}}$ & $\mathbf{R}_{\mathbf{2}}$ & $\mathbf{R}_{\mathbf{3}}$ & $\mathbf{R}_{\mathbf{4}}$ & $\mathbf{R}_{\mathbf{5}}$ & $\mathbf{R}_{\mathbf{6}}$ & Total & Rank \\
\hline Drought & 6 & 5 & 4 & 5 & 4 & 4 & 28 & $2^{\text {nd }}$ \\
Agricultural expansion & 5 & 6 & 6 & 6 & 5 & 6 & 34 & $1^{\text {st }}$ \\
Firewood & 3 & 4 & 5 & 4 & 6 & 5 & 27 & $3^{\text {rd }}$ \\
Charcoal & 2 & 3 & 4 & 2 & 2 & 2 & 15 & $5^{\text {th }}$ \\
Construction & 4 & 2 & 2 & 3 & 3 & 3 & 17 & $4^{\text {th }}$ \\
Urbanization & 1 & 1 & 1 & 1 & 1 & 1 & 6 & $6^{\text {th }}$
\end{tabular}

*Key: where $\mathrm{R}$ represented respondents

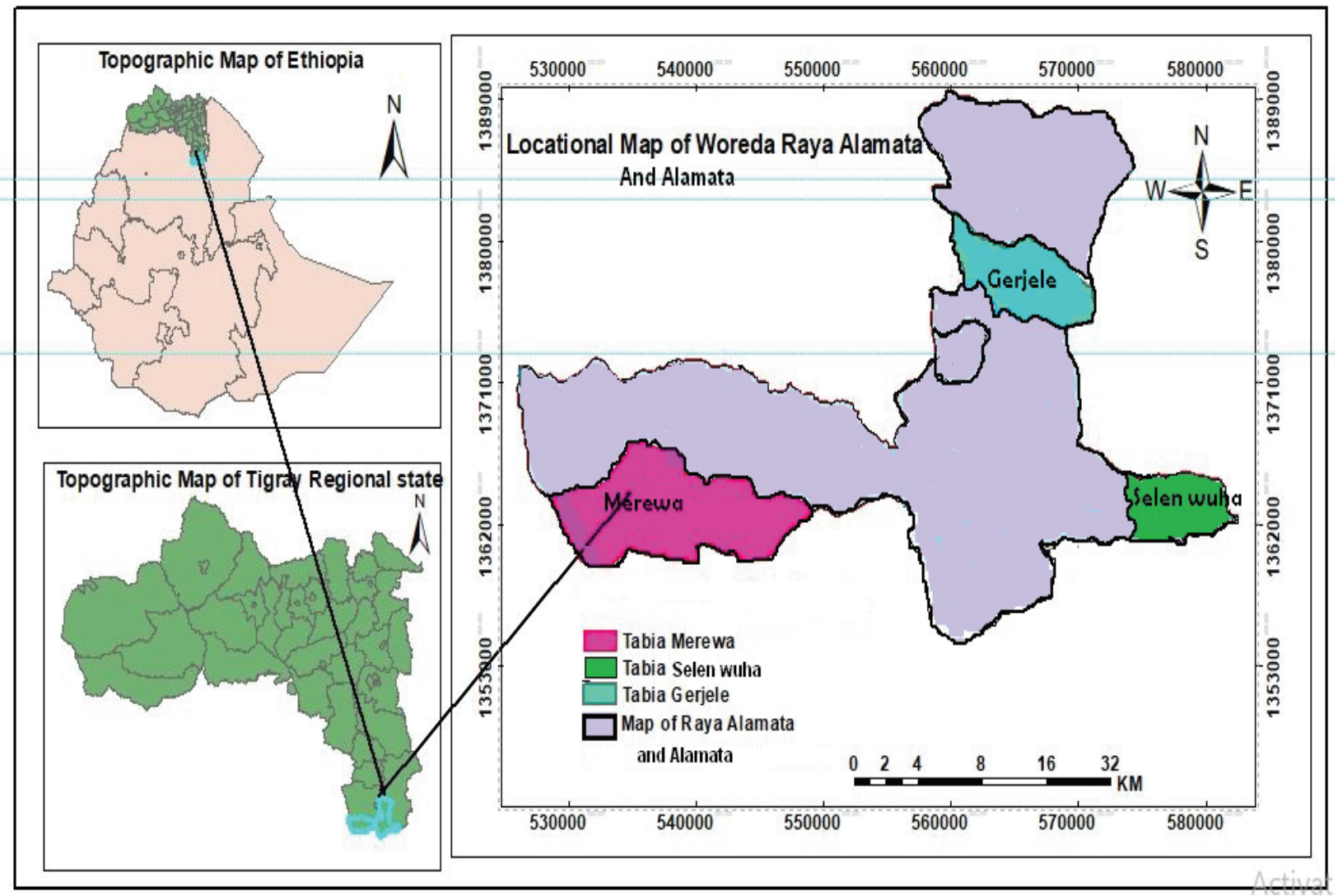

Figure 1: Location map of the study area 


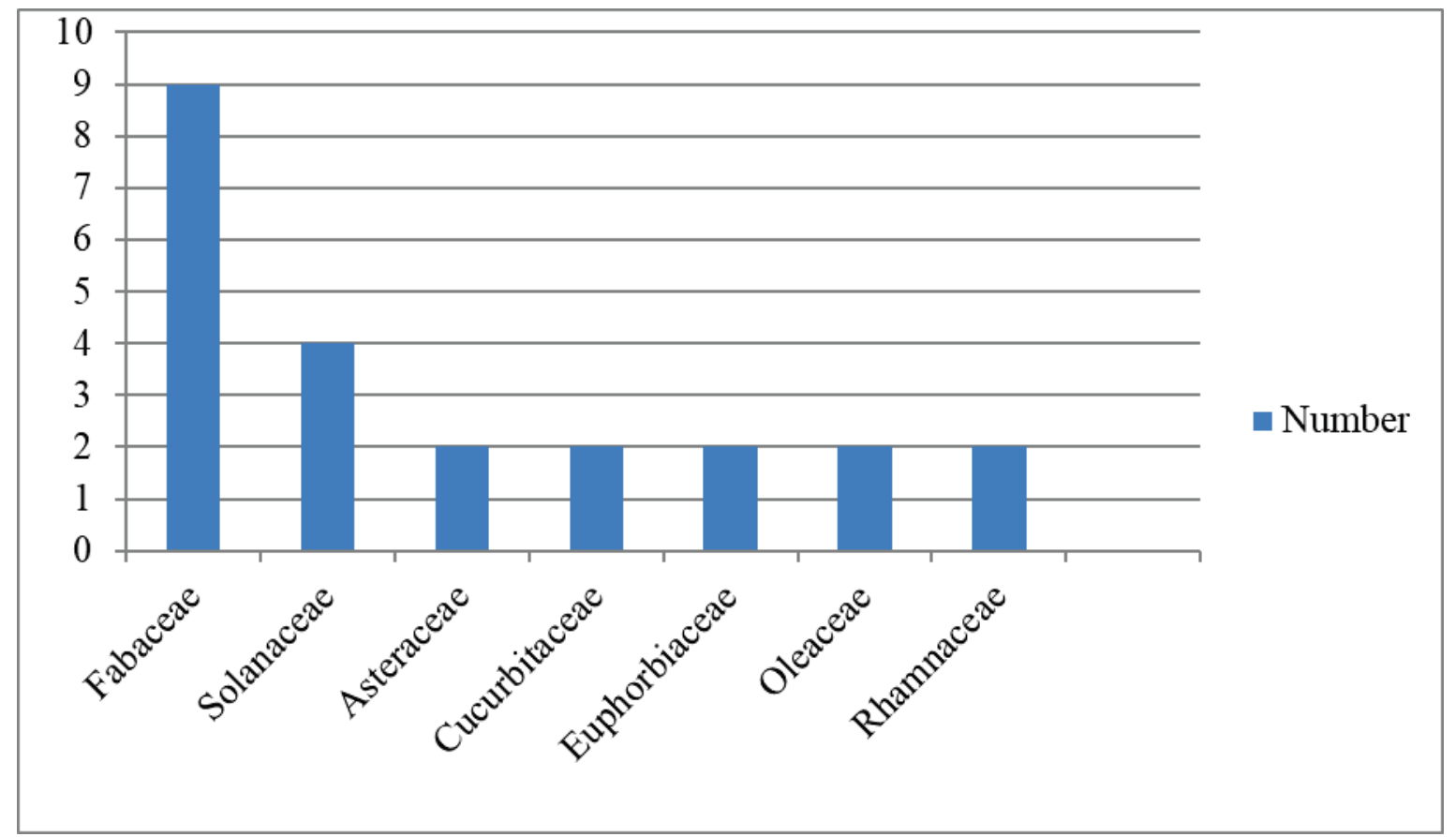

Figure 2: Medicinal plant species composition in terms of families

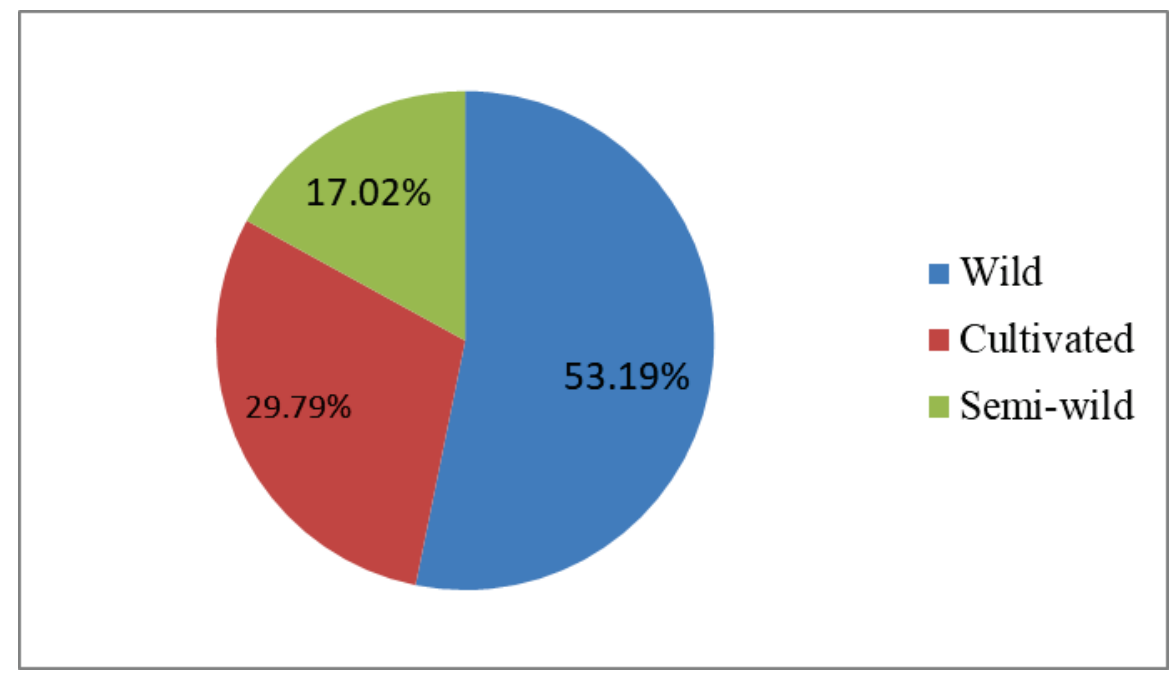

Figure 3: Spatial distribution of medicinal plants

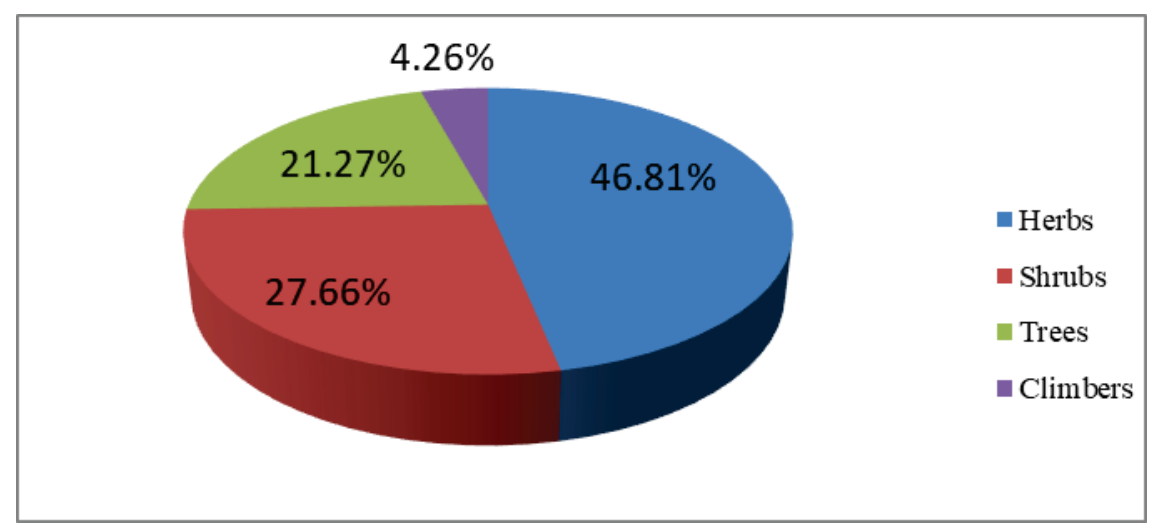

Figure 4: Habits of medicinal plants 


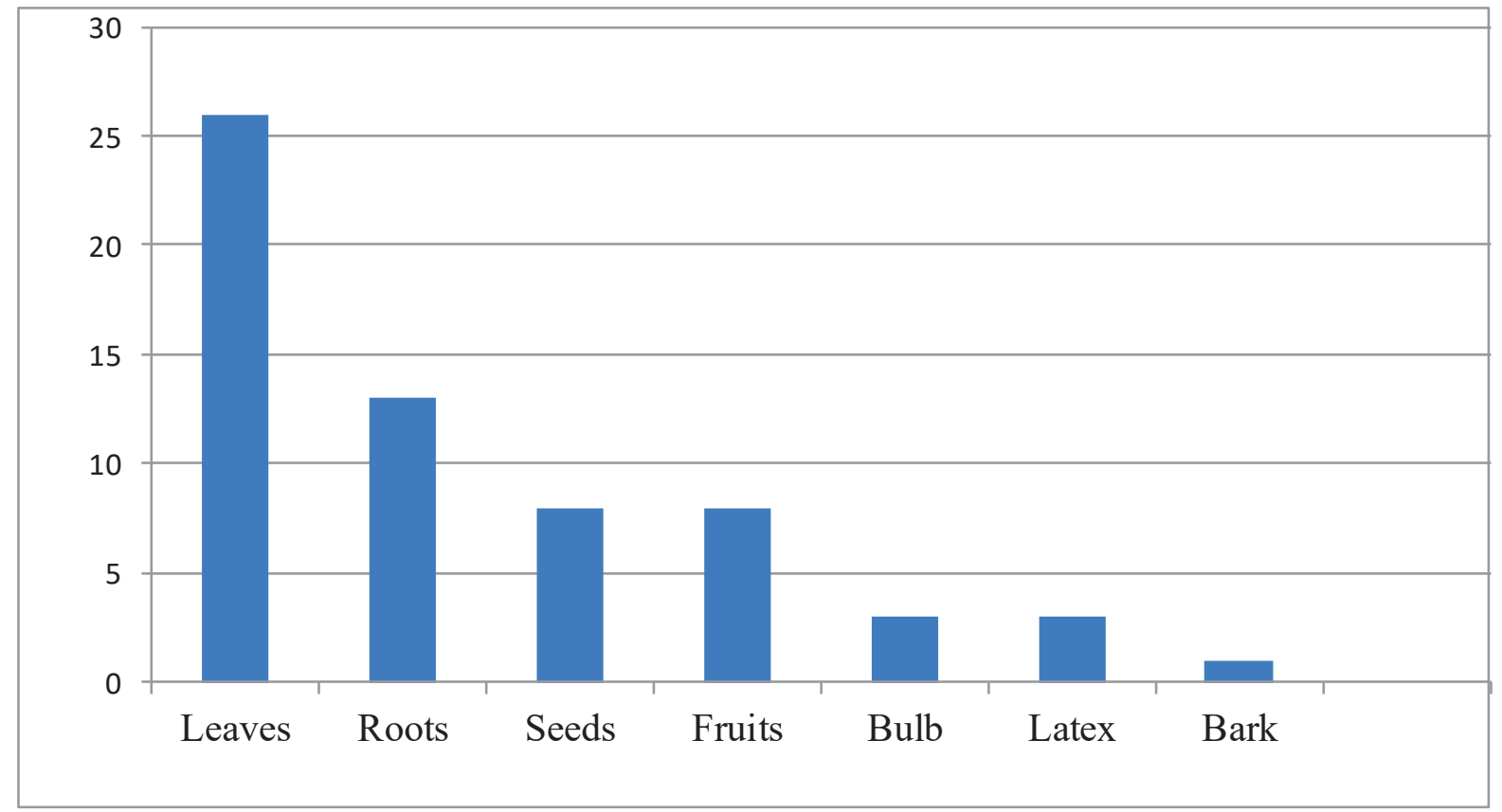

Figure 5: Plant parts used for medicine

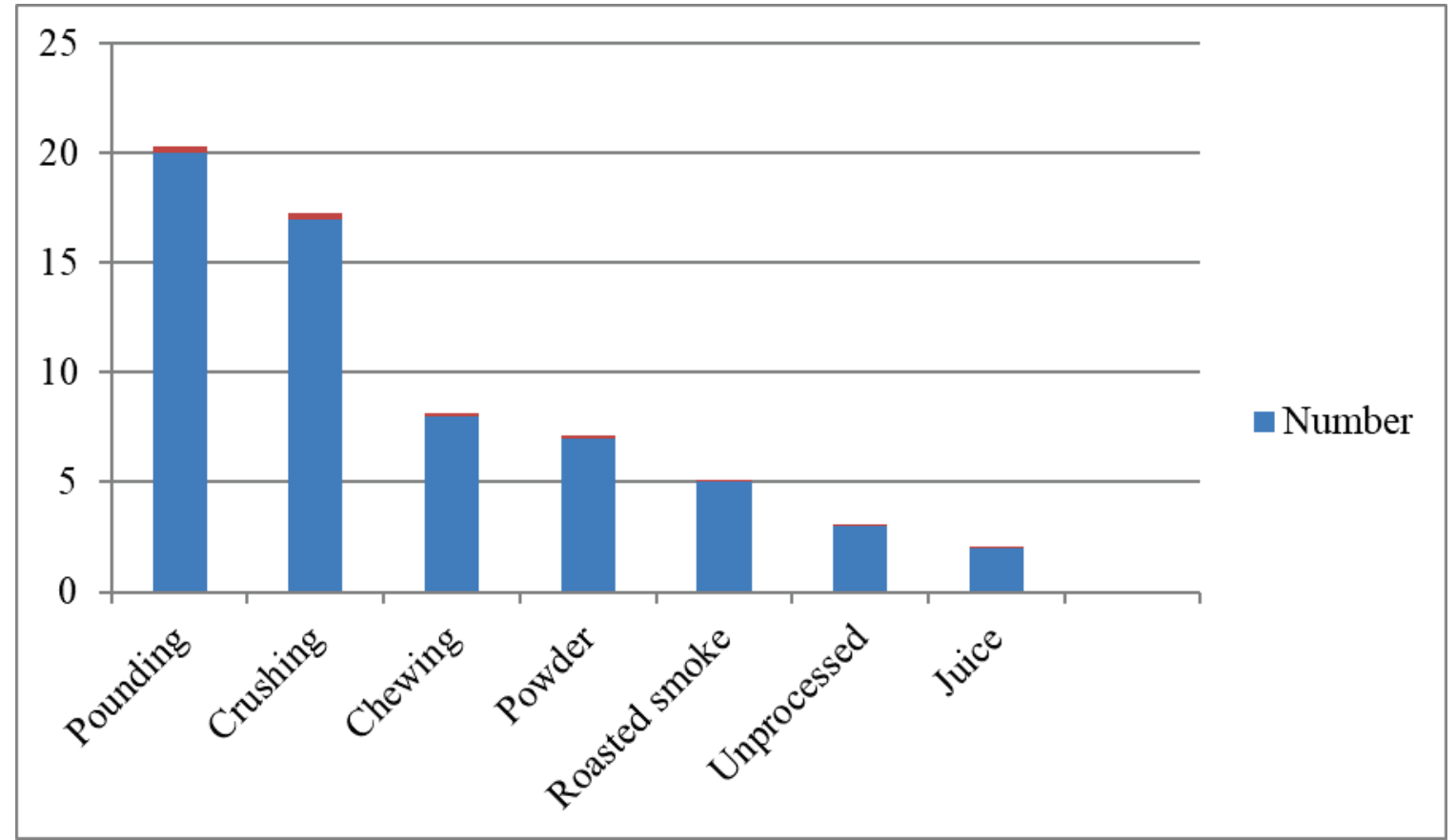

Figure 6: Mode of preparation of traditional medicine 


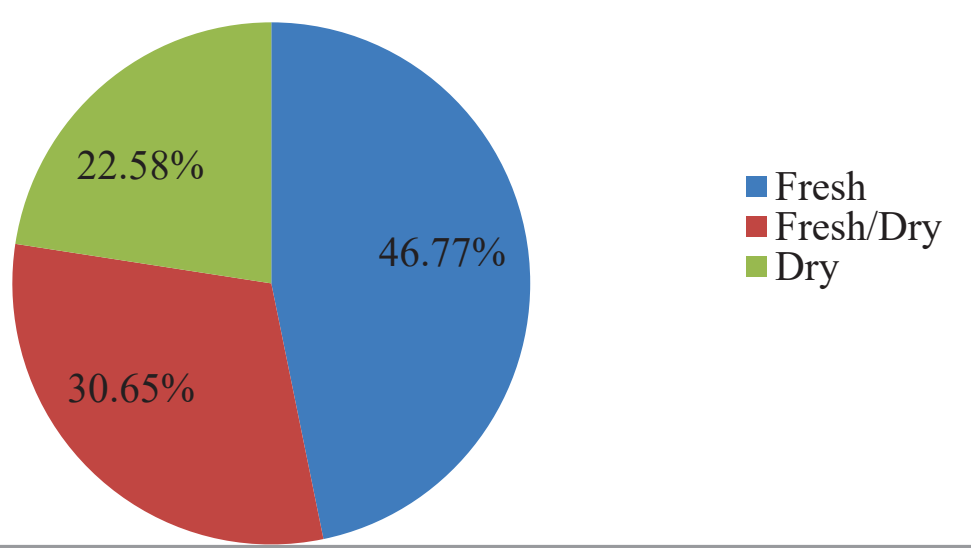

Figure 7: Condition of plant parts for preparation of traditional medicine

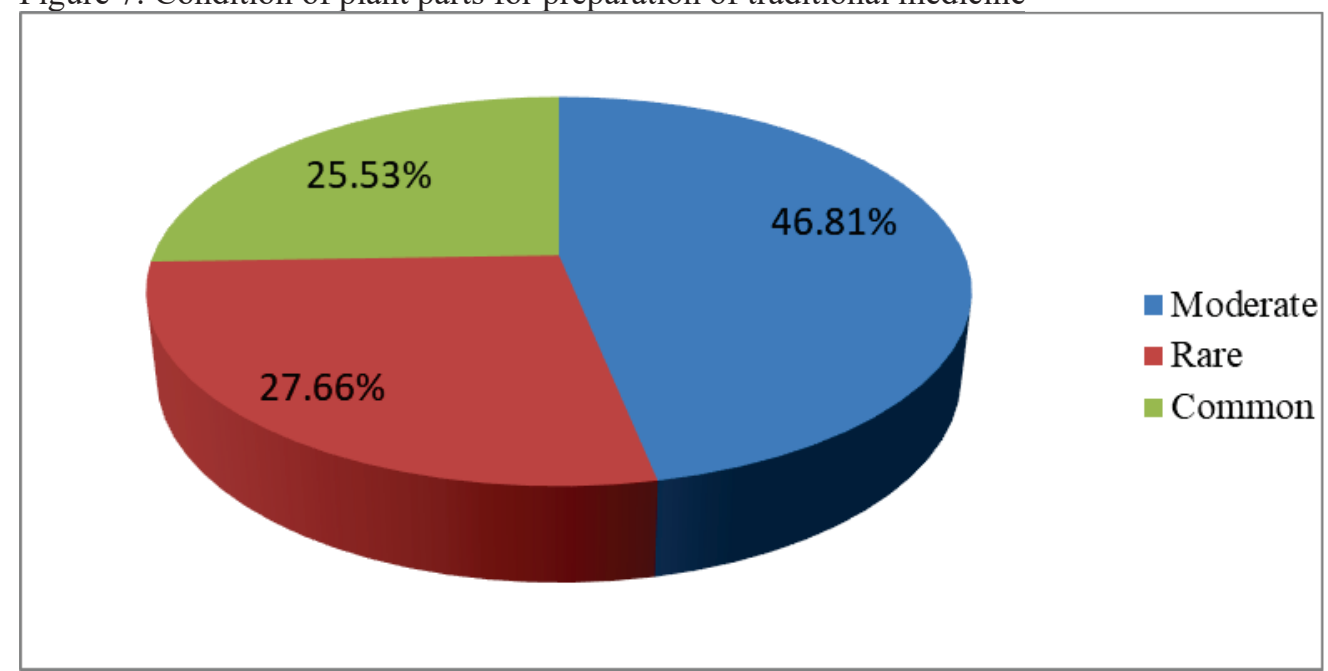

Figure 8: Status of medicinal plants 
Appendix 1: Medicinal plants used to both human ailments and livestock diseases (key: SW=semi-wild, $\mathrm{C}=$ cultivated and $\mathrm{W}=$ wild).

\begin{tabular}{|c|c|c|c|c|c|c|c|c|c|}
\hline No & $\begin{array}{l}\text { Scientific } \\
\text { name }\end{array}$ & $\begin{array}{l}\text { Local } \\
\text { name }\end{array}$ & Family name & Habit & $\begin{array}{l}\text { Part/s } \\
\text { used }\end{array}$ & Source & Used for & $\begin{array}{l}\text { Method of } \\
\text { preparation }\end{array}$ & Administration route \\
\hline \multirow[t]{3}{*}{1} & \multirow[t]{3}{*}{$\begin{array}{l}\text { Aloe } \\
\text { megalacantha }\end{array}$} & \multirow[t]{3}{*}{ Ret } & \multirow[t]{3}{*}{ Aloaceae } & \multirow[t]{3}{*}{ Herb } & \multirow[t]{2}{*}{ Latex } & \multirow[t]{3}{*}{ SW } & $\begin{array}{l}\text { Dislocated } \\
\text { bone }\end{array}$ & $\begin{array}{l}\text { Tying it on the } \\
\text { damaged part }\end{array}$ & External \\
\hline & & & & & & & $\begin{array}{l}\text { External } \\
\text { wound }\end{array}$ & $\begin{array}{l}\text { Cutting fresh leaf } \\
\text { and spreading latex } \\
\text { on wound }\end{array}$ & External \\
\hline & & & & & Leaf & & Malaria & $\begin{array}{l}\text { Crushing fresh } \\
\text { leaves, squeezing } \\
\text { juice, filtering and } \\
\text { drinking }\end{array}$ & Internal \\
\hline 2 & Acacia etbaica & Seraw & Fabaceae & Tree & Root & W & Bronchitis & $\begin{array}{l}\text { Roasting fresh or } \\
\text { dry root and inhaling } \\
\text { smoke }\end{array}$ & Internal \\
\hline \multirow[t]{3}{*}{3} & \multirow[t]{3}{*}{$\begin{array}{l}\text { Trigonella } \\
\text { foenum } \\
\text { graecum }\end{array}$} & \multirow[t]{3}{*}{ Abaeke } & \multirow[t]{3}{*}{ Fabaceae } & \multirow[t]{3}{*}{ Herb } & \multirow[t]{3}{*}{ Seed } & \multirow[t]{3}{*}{$\mathrm{C}$} & $\begin{array}{l}\text { Abdominal } \\
\text { pain }\end{array}$ & $\begin{array}{l}\text { Grinding dry seed, } \\
\text { adding water and } \\
\text { drinking } 1 \text { to } 2 \text { cup }\end{array}$ & Internal \\
\hline & & & & & & & $\begin{array}{l}\text { Swelling } \\
\text { (both) }\end{array}$ & $\begin{array}{l}\text { Grinding fresh or dry } \\
\text { seed, mixing with } \\
\text { beans and rubbing } \\
\text { paste on affected part }\end{array}$ & External \\
\hline & & & & & & & $\begin{array}{l}\text { Dislocated } \\
\text { bone }\end{array}$ & $\begin{array}{l}\text { Immersing dry seed } \\
\text { into water, pounding } \\
\text { and tying on the } \\
\text { injured part to } \\
\text { soften skin }\end{array}$ & External \\
\hline 4 & $\begin{array}{l}\text { Acacia } \\
\text { abyssinica }\end{array}$ & Karwera & Fabaceae & Tree & Leaf & SW & $\begin{array}{l}\text { External } \\
\text { wounds } \\
\text { infestation }\end{array}$ & $\begin{array}{l}\text { Crushing fresh or dry } \\
\text { leaf and tying it on } \\
\text { wound }\end{array}$ & External \\
\hline \multirow[t]{3}{*}{5} & \multirow[t]{3}{*}{$\begin{array}{l}\text { Dodonea } \\
\text { angustifolia }\end{array}$} & \multirow[t]{3}{*}{ Ktkita } & \multirow[t]{3}{*}{ Sapindaceae } & \multirow[t]{3}{*}{ Shrub } & Root & \multirow[t]{3}{*}{$\mathrm{W}$} & Bronchitis & $\begin{array}{l}\text { Roasting dry root, } \\
\text { pasting and inhaling } \\
\text { smoke }\end{array}$ & Internal \\
\hline & & & & & Leaf & & $\begin{array}{l}\text { Dislocated } \\
\text { bone(anima } \\
\text { 1) }\end{array}$ & $\begin{array}{l}\text { Crushing dry leaf tie } \\
\text { on the damaged part }\end{array}$ & External \\
\hline & & & & & & & $\begin{array}{l}\text { Eye } \\
\text { infection }\end{array}$ & $\begin{array}{l}\text { Crushing fresh leaf } \\
\text { and applying } \\
\text { droplets into the } \\
\text { infected eye }\end{array}$ & Internal \\
\hline \multirow[t]{2}{*}{6} & \multirow[t]{2}{*}{$\begin{array}{l}\text { Solanum } \\
\text { mariginatum }\end{array}$} & \multirow[t]{2}{*}{ Engule } & \multirow[t]{2}{*}{ Solanaceae } & Shrub & Root & \multirow[t]{2}{*}{$\mathrm{W}$} & $\begin{array}{l}\text { Abdominal } \\
\text { pain }\end{array}$ & $\begin{array}{l}\text { Chewing fresh root } \\
\text { and swallowing the } \\
\text { fluid }\end{array}$ & Internal \\
\hline & & & & & Fruit & & $\begin{array}{l}\text { Breathing } \\
\text { problem( } \mathrm{Li} \\
\text { vestock) }\end{array}$ & $\begin{array}{l}\text { Pounding fresh fruit } \\
\text { and applying through } \\
\text { the nose }\end{array}$ & Internal \\
\hline 7 & Acacia laeta & Sabansa & Fabaceae & Tree & Leaf & W & $\begin{array}{l}\text { Eye } \\
\text { infection }\end{array}$ & $\begin{array}{l}\text { Pounding fresh leaf } \\
\text { and applying on } \\
\text { affected eye }\end{array}$ & Internal \\
\hline \multirow[t]{2}{*}{8} & \multirow{2}{*}{$\begin{array}{l}\text { Echinops } \\
\text { maracandicus }\end{array}$} & \multirow[t]{2}{*}{ Dander } & \multirow[t]{2}{*}{ Asteraceae } & \multirow[t]{2}{*}{ Herb } & \multirow[t]{2}{*}{ Root } & \multirow[t]{2}{*}{$\mathrm{W}$} & Head ache & $\begin{array}{l}\text { Crushing dry root } \\
\text { and inhaling }\end{array}$ & Internal \\
\hline & & & & & & & $\begin{array}{l}\text { Dislocated } \\
\text { bone } \\
\text { (animal) }\end{array}$ & $\begin{array}{l}\text { Pounding dry root, } \\
\text { tying it on damaged } \\
\text { part }\end{array}$ & External \\
\hline
\end{tabular}


Appendix 2: Medicinal plants used to treat human ailments only (key: $\mathrm{SW}=$ semi-wild, $\mathrm{C}=$ cultivated and $\mathrm{W}=$ wild).

\begin{tabular}{|c|c|c|c|c|c|c|c|c|c|}
\hline No & Scientific name & Local name & Family name & Habit & $\begin{array}{l}\text { Part } / \mathrm{s} \\
\text { used }\end{array}$ & Source & Used for & Method of preparation & $\begin{array}{l}\text { Administration } \\
\text { route }\end{array}$ \\
\hline 1 & $\begin{array}{l}\text { Capparis } \\
\text { tomentosn }\end{array}$ & Harenigama & Capparaceae & Shrub & Leaf & $\mathrm{W}$ & Evil eye & $\begin{array}{l}\text { Placing fresh or dry } \\
\text { leaf on fire for } \\
\text { fumigation }\end{array}$ & External \\
\hline 2 & Olea europaea & Weyra & Oleaceae & Tree & Leaf & SW & Tonsil & $\begin{array}{l}\text { Chewing fresh or dry } \\
\text { leaf and drinking the } \\
\text { fluid }\end{array}$ & Internal \\
\hline 3 & Calpumia aurea & Hatsawits & Fabaceae & Tree & Bark & $\mathrm{W}$ & Bronchitis & $\begin{array}{l}\text { Roasting fresh or dry } \\
\text { bark and inhaling } \\
\text { smoke }\end{array}$ & Internal \\
\hline \multirow[t]{2}{*}{4} & \multirow[t]{2}{*}{ Allium sativum } & \multirow[t]{2}{*}{$\begin{array}{l}\text { Tsaeda } \\
\text { shinkurt }\end{array}$} & \multirow[t]{2}{*}{ Alliaceae } & \multirow[t]{2}{*}{ Herb } & \multirow[t]{2}{*}{ Bulb } & \multirow[t]{2}{*}{$\mathrm{C}$} & Asthma & $\begin{array}{l}\text { Crushing about } 5 \text { fresh } \\
\text { or dry bulbs, mixing } \\
\text { with honey, butter and } \\
\text { consuming one cup } \\
\text { every morning for } 5 \\
\text { consecutive days }\end{array}$ & Internal \\
\hline & & & & & & & $\begin{array}{l}\text { Wound/sor } \\
\text { e/ }\end{array}$ & $\begin{array}{l}\text { Pounding fresh or dry } \\
\text { bulb and tying on the } \\
\text { affected part }\end{array}$ & External \\
\hline 5 & $\begin{array}{l}\text { Carissa } \\
\text { spinarum }\end{array}$ & Agam & Apocyanaceae & Shrub & Root & $\mathrm{W}$ & Evil eye & $\begin{array}{l}\text { Smelling dry root or } \\
\text { crushing, adding to fire } \\
\text { and inhaling smoke }\end{array}$ & Internal \\
\hline 6 & $\begin{array}{l}\text { Hibiscus } \\
\text { micranthus }\end{array}$ & Chena argi & Malvaceae & Herb & Leaf & $\mathrm{W}$ & Wound & $\begin{array}{l}\text { Crushing fresh leaf by } \\
\text { mixing with saliva and } \\
\text { applying on wound }\end{array}$ & External \\
\hline 7 & $\begin{array}{l}\text { Phytolacca } \\
\text { dodecandra }\end{array}$ & Shibit & Phytolacaceae & Climber & Whole & $\mathrm{W}$ & Abortion & $\begin{array}{l}\text { Crushing fresh part, } \\
\text { adding water and } \\
\text { drinking the fluid of } 1 \\
\text { to } 2 \text { glass }\end{array}$ & Internal \\
\hline 8 & $\begin{array}{l}\text { Astragalus } \\
\text { atropilosus }\end{array}$ & Koremedit & Fabaceae & Shrub & Leaf & W & Tooth pain & $\begin{array}{l}\text { Chewing fresh leaf and } \\
\text { holding it on the } \\
\text { diseased tooth }\end{array}$ & Internal \\
\hline 9 & $\begin{array}{l}\text { Artemisia } \\
\text { absinthim }\end{array}$ & Atran & Asteraceae & Herb & Leaf & $\mathrm{C}$ & Evil eye & $\begin{array}{l}\text { Showing fresh leaf and } \\
\text { sleeping on it }\end{array}$ & External \\
\hline 10 & Citrus limon & Lomi & Rutaceae & Tree & Fruit & $\mathrm{C}$ & Measles & $\begin{array}{l}\text { Showing and eating the } \\
\text { fresh fruit }\end{array}$ & Internal \\
\hline 11 & $\begin{array}{l}\text { Solanum } \\
\text { incanum }\end{array}$ & Hintit & Solanaceae & Shrub & Root & W & $\begin{array}{l}\text { Abdominal } \\
\text { pain }\end{array}$ & $\begin{array}{l}\text { Chewing fresh root and } \\
\text { swallowing the fluid }\end{array}$ & Internal \\
\hline 12 & Vicia faba & Ater & Fabaceae & Herb & Seed & $\mathrm{C}$ & $\begin{array}{l}\text { External } \\
\text { wound } \\
\text { "buginji" }\end{array}$ & $\begin{array}{l}\text { Crushing dry seed and } \\
\text { applying on affected } \\
\text { part }\end{array}$ & External \\
\hline \multirow[t]{2}{*}{13} & \multirow[t]{2}{*}{$\begin{array}{l}\text { Heliotropium } \\
\text { steudneri }\end{array}$} & \multirow[t]{2}{*}{ Amamgimel } & \multirow[t]{2}{*}{ Boraginacea } & \multirow[t]{2}{*}{ Herb } & \multirow[t]{2}{*}{ Leaf } & W & Wound & $\begin{array}{l}\text { Pounding fresh leaf and } \\
\text { squeezing liquid on the } \\
\text { affected part }\end{array}$ & External \\
\hline & & & & & & & Dandruff & $\begin{array}{l}\text { Crushing dry or fresh } \\
\text { leaf and applying on } \\
\text { the shaved head of sick } \\
\text { child }\end{array}$ & External \\
\hline \multirow[t]{2}{*}{14} & \multirow[t]{2}{*}{ Coffea arabica } & \multirow[t]{2}{*}{ Buna } & \multirow[t]{2}{*}{ Rubiaceae } & \multirow[t]{2}{*}{ Shrub } & \multirow[t]{2}{*}{ Fruit } & \multirow[t]{2}{*}{$\mathrm{C}$} & $\begin{array}{l}\text { Anti } \\
\text { depressant }\end{array}$ & $\begin{array}{l}\text { Roasting dry fruit and } \\
\text { mixing with hot water } \\
\text { and drinking }\end{array}$ & Internal \\
\hline & & & & & & & Wound & $\begin{array}{l}\text { Roasted the dry fruit } \\
\text { and crushed it and } \\
\text { apply the powder on } \\
\text { the wound }\end{array}$ & External \\
\hline 15 & $\begin{array}{l}\text { Chenopodium } \\
\text { murale }\end{array}$ & Hamedmado & Chenopodiaceae & Herb & Leaf & $\mathrm{W}$ & Dandruf & $\begin{array}{l}\text { Pounding fresh or dry } \\
\text { leaf and applying } \\
\text { cream on shaved head }\end{array}$ & External \\
\hline \multirow[t]{2}{*}{16} & \multirow[t]{2}{*}{$\begin{array}{l}\text { Zingiber } \\
\text { officinale }\end{array}$} & \multirow[t]{2}{*}{ Zingible } & \multirow[t]{2}{*}{ Zingiberaceae } & \multirow[t]{2}{*}{ Herb } & \multirow[t]{2}{*}{ Root } & \multirow[t]{2}{*}{$\mathrm{C}$} & $\begin{array}{l}\text { Abdominal } \\
\text { pain }\end{array}$ & $\begin{array}{l}\text { Chewing fresh or dry } \\
\text { root and swallowing as } \\
\text { fluid }\end{array}$ & Internal \\
\hline & & & & & & & $\begin{array}{l}\text { Common } \\
\text { cold }\end{array}$ & $\begin{array}{l}\text { Pounding fresh or dry } \\
\text { root and adding on } \\
\text { boiled water and } \\
\text { drinking as tea }\end{array}$ & Internal \\
\hline 17 & $\begin{array}{l}\text { Cucumis } \\
\text { ficifolius }\end{array}$ & Ramborambo & Cucur bitaceae & Herb & Fruit & W & $\begin{array}{l}\text { Nail } \\
\text { problem }\end{array}$ & $\begin{array}{l}\text { Pressing and pounding } \\
\text { fresh fruit by the } \\
\text { affected nail and } \\
\text { holding it }\end{array}$ & External \\
\hline \multirow[t]{3}{*}{18} & \multirow[t]{3}{*}{$\begin{array}{l}\text { Datura } \\
\text { stramonium }\end{array}$} & \multirow[t]{3}{*}{ Mestenagr } & \multirow[t]{3}{*}{ Solanaceae } & \multirow[t]{3}{*}{ Herb } & Leaf & $\mathrm{W}$ & Dandruff & $\begin{array}{l}\text { Crushing the dry or } \\
\text { fresh leaf and applying } \\
\text { cream on shaved head }\end{array}$ & External \\
\hline & & & & & & & Abortion & $\begin{array}{l}\text { Crushing fresh leaf, } \\
\text { filtering and drinking } \\
\text { with a cup of tea }\end{array}$ & Internal \\
\hline & & & & & & & Wound & $\begin{array}{l}\text { Crushing dry or fresh } \\
\text { leaf and applying on } \\
\text { affected part }\end{array}$ & External \\
\hline
\end{tabular}




\begin{tabular}{|c|c|c|c|c|c|c|c|c|c|}
\hline No & Scientific name & Local name & Family name & Habit & $\begin{array}{l}\text { Part/s } \\
\text { used }\end{array}$ & Source & Used for & Method of preparation & $\begin{array}{l}\text { Administration } \\
\text { route }\end{array}$ \\
\hline 19 & $\begin{array}{l}\text { Ocimum } \\
\text { lamiifolium }\end{array}$ & Ergo chabe & Lamiaceae & Herb & Leaf & $\mathrm{W}$ & Michi & $\begin{array}{l}\text { Pounding fresh leaf and } \\
\text { drinking with coffee }\end{array}$ & Internal \\
\hline 20 & $\begin{array}{l}\text { Rhamnus } \\
\text { prinoides }\end{array}$ & Gesho & Rhamnaceae & Shrub & Seed & $\mathrm{C}$ & Skin rush & $\begin{array}{l}\text { Burning dry seed in } \\
\text { oven and pounding, } \\
\text { mixing with butter and } \\
\text { applying on affected } \\
\text { skin }\end{array}$ & External \\
\hline 21 & $\begin{array}{l}\text { Commicarpus } \\
\text { plumbagineus }\end{array}$ & Ezinenchiwa & Nyctaginaceae & Herb & Leaf & $\mathrm{W}$ & $\begin{array}{l}\text { Snake } \\
\text { venom }\end{array}$ & $\begin{array}{l}\text { Pounding fresh leaf, } \\
\text { boiling with butter and } \\
\text { water and applying as } \\
\text { cream }\end{array}$ & External \\
\hline 22 & $\begin{array}{l}\text { Jasminium } \\
\text { gratissimum }\end{array}$ & Habitselim & Oleaceae & Climber & Leaf & $\mathrm{W}$ & Tooth pain & $\begin{array}{l}\text { Chewing the fresh leaf } \\
\text { and hold it on the tooth } \\
\text { and take in }\end{array}$ & Internal \\
\hline 23 & $\begin{array}{l}\text { Balanites } \\
\text { aegyptiaca }\end{array}$ & Bedena & Balanitaceae & Tree & Fruit & W & $\begin{array}{l}\text { Amoeba } \\
\text { abdominal } \\
\text { pain }\end{array}$ & $\begin{array}{l}\text { Immersing fresh fruit } \\
\text { into water for } 1 \text { to } 2 \\
\text { days and drinking juice }\end{array}$ & Internal \\
\hline 24 & $\begin{array}{l}\text { Ziziphus } \\
\text { spinachristi }\end{array}$ & Kunkura & Rhamnaceae & Tree & Leaf & $\mathrm{W}$ & Dandruff & $\begin{array}{l}\text { Drying leaf, grinding } \\
\text { and mixing with butter } \\
\text { and rubbing on affected } \\
\text { part }\end{array}$ & External \\
\hline \multirow[t]{2}{*}{25} & \multirow[t]{2}{*}{$\begin{array}{l}\text { Rumex } \\
\text { abyssinicus }\end{array}$} & \multirow[t]{2}{*}{ Mequmeqo } & \multirow[t]{2}{*}{ Polygonaceae } & \multirow[t]{2}{*}{ Herb } & \multirow[t]{2}{*}{ Root } & \multirow[t]{2}{*}{$\mathrm{C}$} & Tooth ache & $\begin{array}{l}\text { Pounding dry root and } \\
\text { drinking it with boiled } \\
\text { coffee }\end{array}$ & Internal \\
\hline & & & & & & & Head ache & $\begin{array}{l}\text { Pounding dry root to } \\
\text { make tea and then } \\
\text { drinking }\end{array}$ & Internal \\
\hline 26 & $\begin{array}{l}\text { Eucalyptus } \\
\text { camaldulensis }\end{array}$ & Keybeharzaf & Myrtaceae & Tree & Leaf & $\mathrm{C}$ & $\begin{array}{l}\text { Eye } \\
\text { infection }\end{array}$ & $\begin{array}{l}\text { Boiling fresh leaf in } \\
\text { water and inhaling its } \\
\text { vapour }\end{array}$ & External \\
\hline 27 & $\begin{array}{l}\text { Justicia } \\
\text { schimperiana }\end{array}$ & Smiza & Acanthaceae & Shrub & Leaf & $\mathrm{W}$ & Jaundice & $\begin{array}{l}\text { Crushed the fresh leaf } \\
\text { and add water and filter } \\
\text { the juice and drink } \\
\text { depend on age }\end{array}$ & Internal \\
\hline 28 & $\begin{array}{l}\text { Moringa } \\
\text { stenopetala }\end{array}$ & Shiferaw & Morigaceae & Tree & Leaf & $\mathrm{C}$ & $\begin{array}{l}\text { hypertensi } \\
\text { on }\end{array}$ & $\begin{array}{l}\text { Drying leaf followed } \\
\text { by crushing, adding a } \\
\text { cup of water, filtering } \\
\text { and drinking }\end{array}$ & Internal \\
\hline 29 & $\begin{array}{l}\text { Euclea } \\
\text { racemosa }\end{array}$ & Dodeho & Ebenaceae & Shrub & Leaf & $\mathrm{W}$ & Evil eye & $\begin{array}{l}\text { Pounding and rubbing } \\
\text { fresh leaf on face and } \\
\text { smelling }\end{array}$ & External \\
\hline 30 & $\begin{array}{l}\text { Oxalis } \\
\text { corniculate }\end{array}$ & Chewamurakit & Oxalidaceae & Herb & Bulb & W & $\begin{array}{l}\text { Tape } \\
\text { worm } \\
\end{array}$ & $\begin{array}{l}\text { Peel the external part in } \\
\text { fresh form and eat it }\end{array}$ & Internal \\
\hline 31 & $\begin{array}{l}\text { Lycopersican } \\
\text { esculentum }\end{array}$ & Tematim & Solanaceae & Herb & Fruit & $\mathrm{C}$ & Fire burn & $\begin{array}{l}\text { Rubbing and pounding } \\
\text { the flesh part on the } \\
\text { burned part }\end{array}$ & External \\
\hline 32 & Cicer arietinum & Shimbra & Fabaceae & Herb & Fruits & $\mathrm{C}$ & $\begin{array}{l}\text { Malaria } \\
\text { gastric }\end{array}$ & $\begin{array}{l}\text { Immersing the fresh } \\
\text { fruit in to water, } \\
\text { filtering after } 1 \text { to } 2 \\
\text { days and taking it as } \\
\text { meal through chewing } \\
\text { and swallowing }\end{array}$ & Internal \\
\hline 33 & Cucurbita pepo & Duba & Cucurbitaceae & Herb & Seed & $\mathrm{C}$ & $\begin{array}{l}\text { Tape } \\
\text { worm }\end{array}$ & $\begin{array}{l}\text { Roasting the dry seed, } \\
\text { and swallowing }\end{array}$ & Internal \\
\hline
\end{tabular}

Appendix 3: Medicinal plants used to treat livestock ailments only (key: $\mathrm{SW}=$ semi-wild, $\mathrm{C}=$ cultivated and $\mathrm{W}=$ wild).

\begin{tabular}{|l|l|l|l|l|l|l|l|l|}
\hline No & $\begin{array}{l}\text { Scientific } \\
\text { name }\end{array}$ & $\begin{array}{l}\text { Local } \\
\text { name }\end{array}$ & Family name & Habit & $\begin{array}{l}\text { Parts } \\
\text { used }\end{array}$ & Source & Used for & $\begin{array}{l}\text { Administration } \\
\text { route }\end{array}$ \\
\hline 1 & $\begin{array}{l}\text { Achyranthes } \\
\text { aspera }\end{array}$ & Gurbie & Amaranthaceae & Herb & Root & W & $\begin{array}{l}\text { Eye } \\
\text { disease(animals })\end{array}$ & Internal \\
\hline 2 & $\begin{array}{l}\text { Agave } \\
\text { sisalana }\end{array}$ & Shihqo & Agavaceae & Herb & Root & SW & $\begin{array}{l}\text { Leech } \\
\text { infestation }\end{array}$ & Internal \\
\hline $\begin{array}{l}\text { Opuntia } \\
\text { ficus }\end{array}$ & Kulkual & Cactaceae & Shrub & Leaf & SW & Fleas infestation & External \\
\hline 4 & $\begin{array}{l}\text { Euphorbia } \\
\text { tirucalli }\end{array}$ & Kinchib & Euphorbiaceae & Shrub & Latex & SW & $\begin{array}{l}\text { Skin } \\
\text { haemorrhoids }\end{array}$ & External \\
\hline 5 & $\begin{array}{l}\text { Pterolobium } \\
\text { stellatum }\end{array}$ & Kanteftefe & Fabaceae & Shrub & Root & W & $\begin{array}{l}\text { Dislocated } \\
\text { bone(animal) }\end{array}$ & External \\
\hline 6 & $\begin{array}{l}\text { Ricinus } \\
\text { communis }\end{array}$ & Gulee & Euphorbiaceae & Shrub & Leaf & W & Horn worm & External \\
\hline
\end{tabular}

